\title{
"TILL THE SIMPLE RELIGIOUS IDEA": AN UNPUBLISHED WHITMAN MANUSCRIPT FRAGMENT
}

\author{
Ed Folsom
}

AN UNPUBLISHED WHITMAN MANUSCRIPT FRAGMENT- on a torn, discolored, and fragile piece of paper-recently entered the Kendall Reed Collection. The manuscript was accompanied by a photograph of Whitman (the 1872 photo by G. Frank Pearsall, numbered 1870s \#3 in the WWQR "Whitman Photographs" issue [Fall/Winter 1986-1987]), on the back of which is a handwritten notation by Horace Traubel: "This portrait of W.W. I send you from papers given to me by him. H.T." The manuscript fragment reads as follows:

till the simplest simple religious idea, becomes part of the tiving live tissue of men and women, and not any longer mere no longer merely a respectable garment, proof not of modesty but of immodesty, that then all religious forms rites will be idle and the same, and neither no one either better nor or worse than another, or better or worse than none-

This manuscript is intriguing because it does not clearly correspond to any published passages in Whitman's writing, though it echoes or anticipates various passages in "Song of Myself" "There was never any more inception than there is now, / . . Nor any more heaven or hell than there is now" [ $L G, 30]$; "Walt Whitman, a kosmos, of Manhattan the son, / Turbulent, fleshy, sensual, eating, drinking and breeding, / . . No more modest than immodest" [LG 52]; "My faith is the greatest of faiths and the least of faiths, / Enclosing worship ancient and modern and all between ancient and modern" $[L G, 78])$. Twice in his prose, Whitman uses the phrase "religious idea," once in Specimen Days, when he celebrates nakedness ("Probably the whole curriculum of first-class philosophy, beauty, heroism, form, illustrated by the old Hellenic racethe highest height and deepest depth known to civilization in those departments - came from their natural and religious idea of Nakedness" $[P W, 152])$, and once in a notebook entry ("A main idea is to be that a brave heroic thought or religious idea, faithfully pursued, justifies itself in time, not perhaps in its own way but often in grander ways" [NUPM, 929]). 
The passage also relates to part of the preface to the 1855 Leaves of Grass, where Whitman does talk about the necessity to cut through the traditional arguments about religion and God in order to see the divinity in the flesh of men and women: "The depths are fathomless and therefore calm. The innocence and nakedness are resumed . . . they are neither modest nor immodest. The whole theory of the special and supernatural and all that was twined with it or educed out of it departs as a dream. [. . .] It is also not consistent with the reality of the soul to admit that there is anything in the known universe more divine than men and women" ( $L G 1855$, vii-viii). It is remarkable how often the "religious idea" in Whitman is "twined" with the idea of nakedness and the idea of the divinity of men and women and of human sexuality. This newly found manuscript, then, may be one of Whitman's early formulations of this convergence, finding the "religious idea" in the very "live tissue of men and women" and urging that the "garment" of religious respectability be removed to reveal the full power and spirituality of the present physical moment.

The University of Iowa

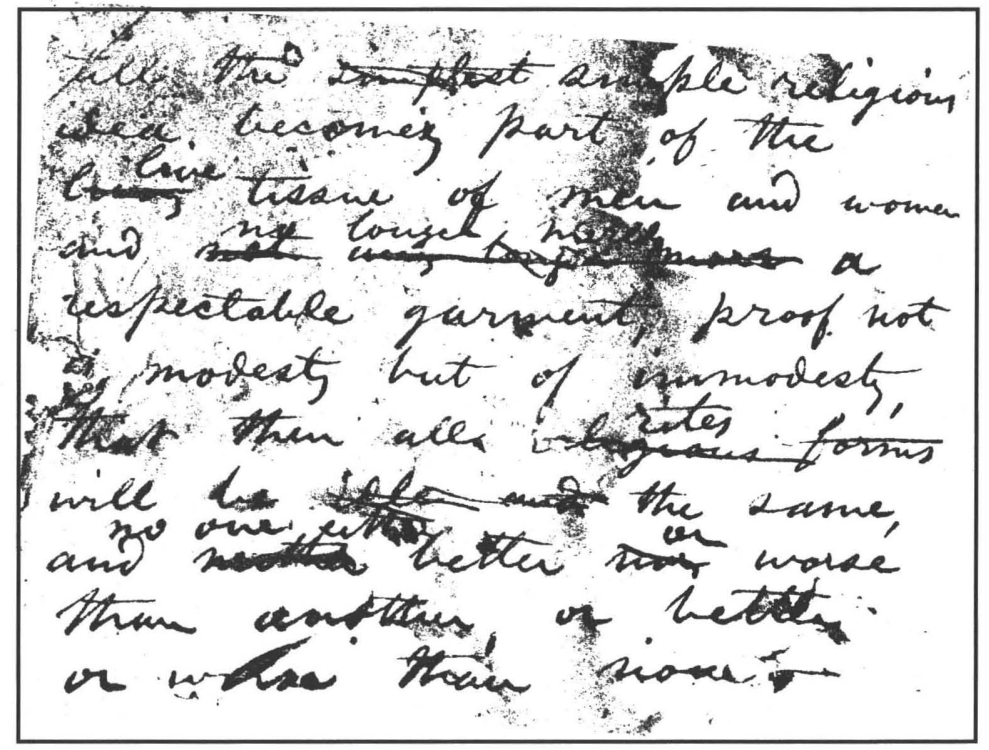

Manuscript Fragment: "till the simple religious idea." Kendall Reed Collection. 